Review

\title{
Economics of Harmful Invasive Species: A Review
}

\section{George Marbuah ${ }^{1, *}$, Ing-Marie Gren ${ }^{1}$ and Brendan McKie ${ }^{2}$}

1 Department of Economics, Swedish University of Agricultural Sciences, P.O. Box 7013, 75007 Uppsala, Sweden; E-Mail: Ing-Marie.Gren@slu.se

2 Department of Aquatic Sciences and Assessments, Swedish University of Agricultural Sciences, P.O. Box 7050, 75007 Uppsala, Sweden; E-Mail: Brendan.Mckie@slu.se

* Author to whom correspondence should be addressed; E-Mail: george.marbuah@slu.se; Tel.: +46720436153 .

Received: 5 May 2014; in revised form: 26 June 2014 / Accepted: 3 July 2014 /

Published: 15 July 2014

\begin{abstract}
The purpose of this study is to review theoretical and empirical findings in economics with respect to the challenging question of how to manage invasive species. The review revealed a relatively large body of literature on the assessment of damage costs of invasive species; single species and groups of species at different geographical scales. However, the estimated damage costs show large variation, from less than 1 million USD to costs corresponding to $12 \%$ of gross domestic product, depending on the methods employed, geographical scale, and scope with respect to inclusion of different species. Decisions regarding optimal management strategies, when to act in the invasion chain and which policy to choose, have received much less attention in earlier years, but have been subject to increasing research during the last decade. More difficult, but also more relevant policy issues have been raised, which concern the targeting in time and space of strategies under conditions of uncertainty. In particular, the weighting of costs and benefits from early detection and mitigation against the uncertain avoidance of damage with later control, when the precision in targeting species is typically greater is identified as a key challenge. The role of improved monitoring for detecting species and their spread and damage has been emphasized, but questions remain on how to achieve this in practice. This is in contrast to the relatively large body of literature on policies for mitigating dispersal by trade, which is regarded as one of the most important vectors for the spread of invasive species. On the other hand, the literature on how to mitigate established species, by control or adaptation, is much more scant. Studies evaluating causes for success or failure of policies against invasive in practice are in principal non-existing.
\end{abstract}


Keywords: alien invasive species; economics; management; literature review

\section{Introduction}

Intentional and unintentional introductions of invasive species into new environments have had, and continue to have profound ecological, human, social and economic effects at national, regional and global scales. Natural habitats of indigenous species have been disturbed, ecosystem functioning degraded, and aesthetics of natural environments impaired due to biological invasions. This worrying phenomenon has received recognition from ecologists, economists and public entities with environmental protection and management oversight. For example, [1] estimates damage costs of 79 harmful invasive species (HIS) to be some $\$ 185$ billion at the maximum, which corresponds to $1.4 \%$ of GDP (gross domestic product) of the US in 1993. Later studies also indicate large damage costs as related to GDP, up to $12 \%$ (see review in [2] and Table 1 in Section 3). The damages and their causes are much explained by economic activities; as vectors of HIS through international trade and as drivers increasing ecosystem vulnerability through changes in land uses and environmental pollution. This, in turn, implies that strategies for managing HIS can be found in economic solutions to these causes and their effects. Non-economic factors that influence HIS introduction include among others activities undertaken for the purposes of deriving non-material benefits from species' introduction for aesthetics, educational (e.g., ornamental plants for horticultural studies; invasive fish for aquaculture experiments, etc.) and cultural heritage (e.g., religious values).

However studies on the economics of biological invasive species and their associated problems were scarce in the mainstream economic literature, until recently. In the last few decades, the economic field has been witnessing a relative explosion of both theoretical and empirical expositions aimed at shedding light on the economic problem of invasive species. In principle, we can identify three main questions addressed in this literature; $(i)$ what is the damage cost of HIS? (ii) which is the best management strategy? and (iii) which policy instruments should be used in order to affect peoples' behavior? The literature on the first question arose relatively early, some studies are found in 1980s, and have been subject to reviews in mid 2000s [3-5]. These reviews showed large differences in estimated damage costs of single species, which is explained by differences in methods applied, and the spatial and dynamic scale of the studies. The two other questions started to be addressed and analyzed in the economic literature approximately 20 years later. Some of this literature is reviewed in [6], who concluded that much of the literature so far was theoretical and in its infancy. Nevertheless, [6] pointed out important lessons that were already apparent, such as the need to use tariffs on trade or inspections of cargos with care, given they can be counter-productive and even increase the risk of HIS, as well as the trade-off between early detection and response and risk of spending large resource on invasive species that would not cause any harm.

Here, we provide an updated review of the literature on the economics of invasive species management. In particular we provide an overview of recent developments in economics, and which 
challenges remain. We review both theoretical and empirical studies addressing various management strategies and using different methodological approaches. The biological invasion chain, commonly applied on the ecological literature, serves as a point of departure for the review, which is discussed in the next section. The remaining part of the study is structured around the three main questions raised in the economic literature. Section 3 then contains brief review of studies on estimates of damage costs of HIS, and the subsequent sections review studies on efficient HIS management and choice of policy instruments. The paper ends with a discussion and concluding remarks.

\section{Invasion Chain and Management Strategy}

Biological invasions as an uncertain or stochastic process comprise four stages-introduction, establishment, naturalization and spread/dispersal, and damage creation. In the first stage, species are conveyed from their previous range by some means and routes, called the "vector" and "pathway" respectively. They are consequently transported and introduced into a new environment either intentionally (e.g., importation of exotic plants for aquaculture or horticultural production) or unintentionally (e.g., organisms found in ballast water of ships or soil of potted plants; pests/viruses carried by humans). The number of individuals surviving after their release or escape into the novel environment depends both on the species-specific traits (e.g., environmental tolerances), and the length and harshness of the pathway [7]. Next in the process is the establishment of the species population in their new location, when growth and reproduction gathers pace. With an increase in population, the species then spreads both within and then beyond the system it originally invaded, and, in the final stage, may cause considerable ecological, human health or economy-wide damage. Nevertheless, typically only 10 percent of imported (accidentally brought into the country) and/or introduced (those found in the wild) species are likely to become successful invaders or established (found outside control or captivity as a potentially self-sustaining population) $[8,9]$. This is the much publicized tens rule quoted "...the statistical rule holds that 1 in 10 of those imported appear in the wild (introduced or casual), 1 in 10 of those introduced become established, and that 1 in 10 of those established become a pest" [8]. The caution here is that the interpretation of the tens rule is dependent on the precision with respect definition of "imported", "introduced", "established" and "pest" or HIS. Notable exceptions to the tens rule have, in recent times been established. A review by [10] reveal that mean invasion success of animals from one of step of the invasion chain to another is about five times more than what is suggested by the tens rule. This is further corroborated by [11] in a study of introduced mammals and birds.

Once established, invasive species are notable for their capacity to rapidly transform both structural and functional properties of ecosystems over remarkably short time scales [12,13]. While newly colonized alien species may spend decades present with low abundances and minimum ecological impact, once they enter the invasive phase, they can rapidly induce changes in the abundance and distribution of native species, causing local extinctions and large shifts in community structure [14]. Such impacts are relatively well-studied. However, it is also recognized that HIS also alter the magnitude and stability of ecosystem functioning, and delivery of supporting, provisioning, regulating and recreational/cultural ecosystem services [12,15]. Furthermore, evidence has recently emerged that dramatic ecological changes can occur as a result of interactions between 
species invasions and other agents of global change, including changes to climate and nutrient cycles [16-18]. Many HIS are tolerant species with rapid growth rates, allowing them to rapidly exploit excess nutrients and outcompete native species, particularly in systems subjected to additional abiotic or biotic disturbances $[16,18]$. HIS also often carry new pathogens into the invaded areas, which can act as drivers of disease epidemics, representing a substantial threat to the biodiversity of native organisms [12,19], and destabilizing ecosystem functioning, and ecosystem service delivery [20,21]. Finally, when reaching the final stage, the impact of invasive species on ecosystem services can be large [22].

Management strategies available to the decision-maker along the invasions chain include prevention, early detection, rapid response and eradication, control/mitigation and adaptation (Figure 1).

Figure 1. Stages common to all invasions by nonindigenous species (left column), and major policy and management options (right column) associated with each stage of invasion. From the top to the bottom of the left column, each arrow is thinner than the preceding one because the proportion of species that proceeds from one step to the next is less than the previous one. Nevertheless, because the number of species entering pathways is increasing as global trade increases, the number of species causing harmful impacts is increasing with time.
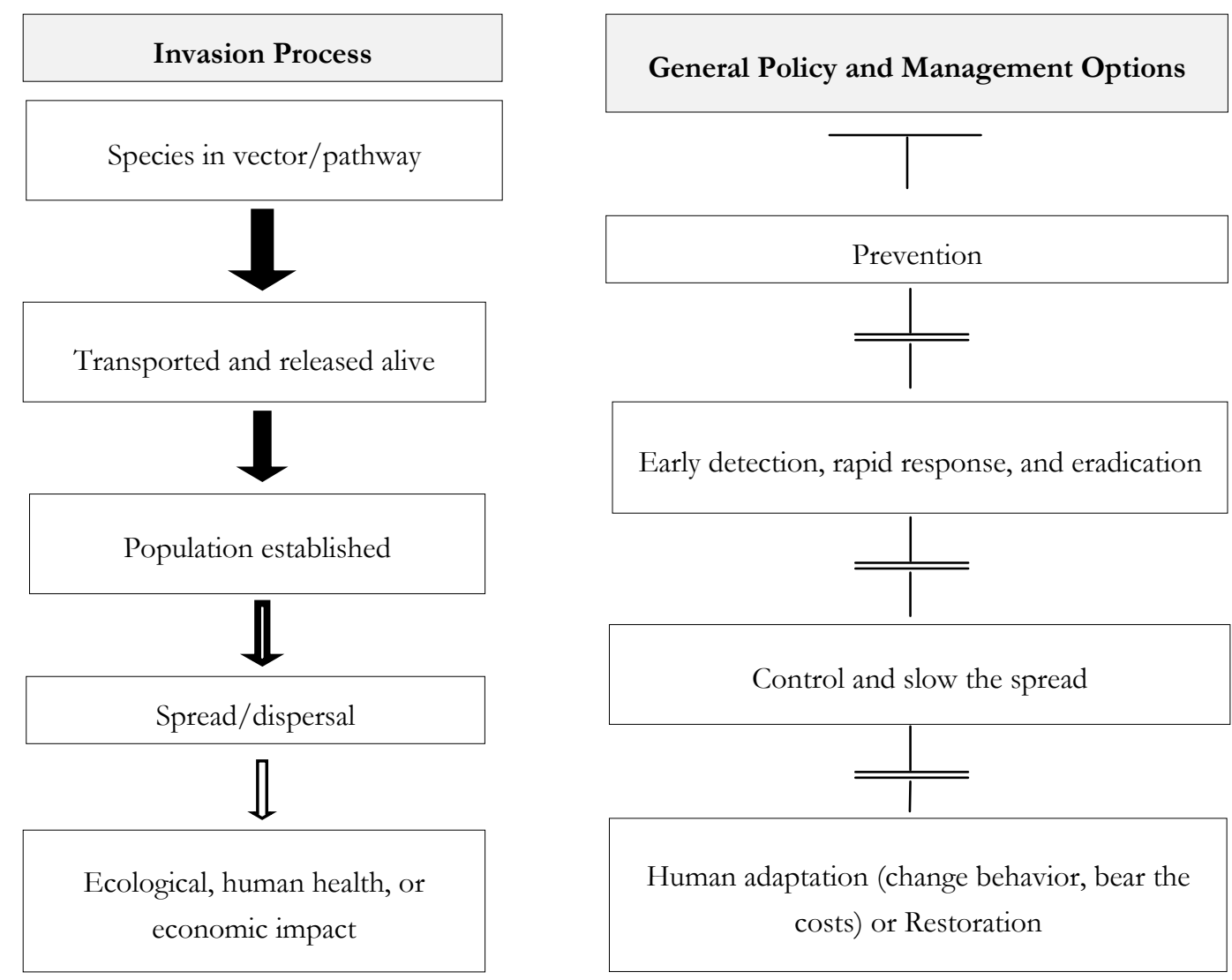

Source: Adapted and modified from [7,23]. 
Prevention involves measures, such as inspection of ships and containers at the port of entry, which aim at reducing the likelihood of a species entering a new host region. Action in the second stage, early detection and rapid response (EDRR), encompasses timely response management strategies aimed at detected species (in small populations) that slip through prevention efforts. Mitigation and control involve actions that reduce the growth and spread of an established species, such as construction of physical barriers in streams to prevent the spread of invasive crayfish. The final option is adaptation in situ to the invader which can involve chemical application (e.g., use of pesticides) and harvesting of the invasive species [6,24].

Generally, invasive species management along the invasion chain is thought of as the "weakest link" public good in the sense that it is nonexclusive and non-rivalrous [25]. Its provision benefits everyone in terms of enhanced protection to human, animal and plant health and the consequent effect on productivity improvements in agriculture, forestry, aquaculture and fisheries [26]. Given its public good characteristics, invasive species control will be undersupplied if left to the market to produce, given the incentive to "free ride", hence creating market inefficiencies - this justifies the need for some (public) policy to correct the externality thus created. A classical example of the "public good" element in the prevention of biological invasions in the case of a national quarantine policy to protect against some invasive pathogens is exemplified by [25]. The quarantine program reduces the risk to everybody in the country - the benefits of which are neither rival nor exclusive. Provision of the quarantine service and the benefits to all people does not affect the cost of quarantine not reduce the benefits of quarantine to others. Now, given the nonexclusive nature of public goods, economic agents have a rather strong incentive to free-ride on the efforts of others. The prevention of these potentially noxious invasive species, if left to the market, would be undersupplied - a case of socially sub-optimal control, [25] conclude that although the providers of the quarantine service may be private, the quarantine of nonindigenous species is typically a public service.

A common theoretical approach in economics for answering the three questions, i.e., estimating damage costs of HIS and for identifying optimal control strategies, is to use bio-economic modeling. This implies an integration of models describing biological processes with those presenting economic behavior. An evaluation of the optimal management objective requires that given control costs (depends on amount being controlled and size of invasion being controlled), the decision-maker chooses control at each point in time minimize expected discounted control costs and invasion damages over time (both costs and damages must be measured in similar unit currency so they can be summed) to a biological transition function for invasion constraint. Alternative objectives such as minimization of costs of eradication or adaptation (containment) of an invasion or maximization of amount of control subject to a budget constraint have also been used in other studies [27].

\section{Damage Costs of Invasive Species}

The magnitude of damage costs of an invasive species depends on the probabilities of passing each of the stages in the invasion chain in Figure 1, and on impacts on different ecosystem services. The costs of the impacts are then measured as the difference in the value of ecosystem services with and without the invader under study. This requires information and data not only on the invader as such, but also on alternative developments of the ecosystems under study. For example, an invasive aquatic 
weed causing impaired bathing water quality could be replaced by an endemic weed with the same effects. In this case, there would not be any costs of invader. The information is needed irrespective of ex-ante or ex-post estimates. In case of ex-ante estimates, the status without the invader is known, but the effects are unknown, and vice versa for ex-post studies. However, although relatively simple in theory, it is very difficult to obtain necessary data on the invasion chain, and environmental impacts under different scenarios, and on the probable development of the invaded systems had the invasion not occurred.

Most of the studies reviewed in this section are ex-post evaluation where damage costs of established HIS are calculated. Starting in early 1960s there is now a large body of literature in environmental economics on methods for assessing values on environmental impacts in monetary terms (see review in [28]). Monetary values are assigned to the impacts perceived by humans, such as harvest losses, or impacts on health and biodiversity. Some of these values can be traded on the market, such as losses in crop and timber harvests, and values are then obtained by means of market prices. Other values, such as improved health and biodiversity, are not traded, and their assessments need to be obtained in other ways. In principle, we identify two types of approaches: preferences obtained directly from hypothetical markets and revealed, directly or indirectly, through real markets. Both these methods have their pros and cons, which are related to the two types of values of a single non-market service, such as biodiversity, that are usually estimated; use and non-use values. Use values refer to the utility experienced by actually using a service, where recreational values of fishing provide one example. Non-use values refer to values assigned to have the option to use a resource in the future, or simply to the pure existence of the service as such. The method resting on hypothetical market has the ability to estimate both these types of values, which the revealed preference method does not have. Both types of methods share two types of difficulties: One is how to find measurement on a continuum of environmental changes, and not only one or few, and the other is how to derive estimates for several simultaneous changes at an ecosystem, such as improved fishing and bathing opportunities. Furthermore, it is well known that calculations of effects can be made only under conditions of risk and uncertainty, which requires assessment of monetary values under these conditions. Methods have been developed in order to resolve this problem, such as the choice experiment methods, but the issue of measuring preference formation under stochastic and long term conditions remains.

The application of the two methods for measuring preferences requires quantification of the environmental or ecological impacts of the invasive species, which may be difficult or even impossible to achieve. In this case, a common approach used is the so-called cost based method. This method measures costs for measures along the invasion chain to control the invader and its damages. The underlying justification for the method is that society would not bear these costs unless they are covered by perceived values. This method has quite often been applied to the estimation of damage cost of invasive species, the literature of which started in the 1980s. Today, there is large variation in studies and assessments with respect to both methods, scale and scope of species and regions. Here, we distinguish between large scale and scope studies which include several groups of species and sometimes regions, and studies focused on single species. Starting with the large scale studies, there is considerable variation in the estimates (Table 1). 
Table 1. Studies with national scale and estimates of damage costs of invasive species (billion USD per year in 2008 prices and \% of GDP).

\begin{tabular}{ccccccccccc}
\hline & US & $\begin{array}{c}\text { Aust } \\
\text { ralia }\end{array}$ & $\begin{array}{c}\text { South } \\
\text { Africa }\end{array}$ & India & Brazil & UK & Ireland & Germany & Sweden & Canada \\
\hline Billion & $131-185^{1} ;$ & $7.7^{2}$ & $3.9^{2}$ & $117^{2}$ & $47^{2}$ & $15^{2}$ & $0.4^{4}$ & $1.9^{5}$ & $3.3^{6}$ & $15^{7}$ \\
$\begin{array}{c}\text { USD/year } \\
121^{2} ; 220^{3}\end{array}$ & & & & & $0.4 ;$ & & & & \\
$\begin{array}{c}1.0-1.4 ; \\
\text { GDP }\end{array}$ & $0.9 ; 1.7$ & 1.0 & 1.4 & 12 & 4.5 & $\begin{array}{c}0.01 \\
<0.001\end{array}$ & & 0.1 & 0.9 \\
\hline
\end{tabular}

${ }^{1}[1],{ }^{2}[29],{ }^{3}[30],{ }^{4}[31],{ }^{5}[32],{ }^{6}[2],{ }^{7}[33]$.

The results presented in Table 1 show a large variation in estimated costs, ranging between less than $0.001 \%$ of GDP to $12 \%$. The relatively large values are obtained for species causing production losses in agriculture as calculated by [29]. [1] also show relatively high damage costs and provides one of the first large scale and scope study and reports both ecological and economic impacts of 79 noxious species over the period 1906-1991. In a worst-case scenario for 15 potential high-impact nonindigenous invasive species, they report a future economic loss of another $\$ 134$ billion. For noxious aquatic weeds, a cumulative increase of only three harmful fish species and aquatic invertebrates would cause a total of $\$ 631$ million and \$1.6 billion, respectively to the US (see [1] for detailed estimates).

Environmental and economic costs associated with nonindigenous invasive species in the US are estimated [30,34,35]. Out of the 50,000 introduced nonindigenous species into the US, only 5,000 are considered harmful [34]. Their results show that if they had been successful at assigning monetary value to species extinctions and losses in biodiversity, ecosystem services and aesthetic impairment, the actual costs of destructions from nonindigenous species would be several times higher than \$137 billion per annum. In an updated study of the US, [30] considered 6000 harmful alien species, and estimated annual environmental damages and losses of approximately most $\$ 120$ billion. Invasive mammals and birds (wild horses and burros, feral pigs, mongooses, rats, cats, dogs, pigeons, starlings, brown snake, and fish) would cause major environmental and economic losses of $\$ 46$ billion per annum in damage and control costs per annum in the US. Further, economic damages from nonindigenous species invasions in the US, UK, Australia, South Africa, India and Brazil amounts to more than $\$ 336$ billion [29]. The study by [30] and others have been critiqued for assuming no adjustment of economic behavior to changing market conditions from HIS. This assumption is often premised on fixed or exogenous prices to the economic system which is deemed unrealistic since there are often behavioral adjustments (to income, output and substitution effects) by people and markets to biological conditions such as HIS with the resultant feedbacks making prices endogenous [36]. The result is that these "fixed-prices" models typically overestimate damages costs or financial impacts from HIS. By accounting for people's adaption to invasive emerald ash borer (Agrilus planipennis) in their model for Ohio, [36] estimate annual damages caused by the beetle to be $\$ 70$ million compared to exogenous price models with estimated damages within the range of \$377-\$967 million.

The total costs of 13 alien invasive species in Sweden has been estimated, with an average cost of $\$ 3.3$ billion [2]. Another study estimates economic impacts on various sectors (agriculture, forestry, 
aquaculture and fisheries, tourism, construction, transport, human health) of both invasive and non-native species to total $\$ 0.4$ in total for Ireland and Northern Ireland [31].

However, these large scale and scope studies apply relatively simple methods for assessing damage costs, where actual costs of control or production losses have been the main sources of damage. Results from [1] and [29] have been heavily criticized for failing to incorporate impacts on ecosystem services or explicit consideration of potential benefits provided by some of the invasive species. Also, failure to use systematic empirical cost estimation methods and the anecdotal nature of their estimates are seen as major flaws [37].

Studies that are more focused in scope and/or scale, which calculate damage costs of only one species or group of species, were carried out first in the 1980s, and there exist today several reviews of such single species studies [3-5]. Two of them, [3,5], review studies on damage costs of aquatic alien species, and [4] provide a survey of studies on damage and mitigation costs of alien species in general. In Table 2 we present results of these reviews and give some examples of single species studies. For each study, we also inform on species and region under study, type of cost, and result.

Table 2. Reviews and examples of studies on damage costs of single species or group of species.

\begin{tabular}{|c|c|c|c|}
\hline & Species and region & Type of damage costs & $\begin{array}{l}\text { Cost in billion USD/year } \\
\text { or per person/year }\end{array}$ \\
\hline \multicolumn{4}{|c|}{ Surveys } \\
\hline$[3]$ & Aquatic weed, US & Production losses, recreational values & $1-10$ \\
\hline$[4]$ & Fynbos, South Africa & Production losses, recreational values & $0.07-12$ \\
\hline$[4]$ & $\begin{array}{l}\text { Weeds, Australia, New } \\
\text { Zealand, }\end{array}$ & $\begin{array}{l}\text { production losses in agriculture, } \\
\text { forestry and fishery }\end{array}$ & $0.2-1$ \\
\hline$[5]$ & Sea Lamprey, US & $\begin{array}{l}\text { Production losses in fishery, } \\
\text { restoration costs, recreational values }\end{array}$ & $0.03-5$ \\
\hline$[5]$ & Ruffe, US & Losses to sport fishery, control costs & $0.01-0.6$ \\
\hline$[5]$ & $\begin{array}{l}\text { Zebra mussel, US and } \\
\text { Canada }\end{array}$ & $\begin{array}{l}\text { Destruction cost on facilities (power } \\
\text { plants etc) }\end{array}$ & $0.1-5$ \\
\hline \multicolumn{4}{|c|}{$\begin{array}{l}\text { Examples of non- } \\
\text { survey studies: }\end{array}$} \\
\hline$[38]$ & Comb jelly in Black Sea & Production loss from anchovy fishery & 0.02 \\
\hline$[39]$ & $\begin{array}{l}\text { Aquatic plants, } 13 \text { Florida } \\
\text { lakes, US }\end{array}$ & Production loss from fishery & 6.0 \\
\hline$[40]$ & Signal crayfish, in Sweden & $\begin{array}{l}\text { Production loss in endemic noble } \\
\text { crayfish }\end{array}$ & 8/person \\
\hline$[41]$ & $\begin{array}{l}\text { Yellow floating heart, lake in } \\
\text { Sweden }\end{array}$ & Recreational values & 90/person \\
\hline$[42]$ & US & Estate market value & $\begin{array}{l}0.0002 \text { marginal cost of an } \\
\text { infested lake }\end{array}$ \\
\hline$[43]$ & $\begin{array}{l}\text { Zebra mussel in Great lakes, } \\
\text { US Canada }\end{array}$ & $\begin{array}{l}\text { Aquaculture, sport fishery, boats, } \\
\text { aesthetic }\end{array}$ & 3.5 \\
\hline
\end{tabular}


Table 2. Cont.

\begin{tabular}{|c|c|c|c|}
\hline & Species and region & Type of damage costs & $\begin{array}{l}\text { Cost in billion USD/year } \\
\text { or per person/year }\end{array}$ \\
\hline \multicolumn{4}{|c|}{$\begin{array}{l}\text { Examples of non- } \\
\text { survey studies: }\end{array}$} \\
\hline [44] & $\begin{array}{l}\text { Zebra mussel in Lake } \\
\text { Okeechobee, Florida, US }\end{array}$ & $\begin{array}{l}\text { Consumptive water uses, recreational } \\
\text { angling and wetland ecosystem } \\
\text { services }\end{array}$ & 0.24 \\
\hline [45] & $\begin{array}{l}\text { Invasive upland plants, } \\
\text { Florida, US }\end{array}$ & Reduce flow of forestland benefits & 0.87 \\
\hline [46] & $\begin{array}{l}\text { Wood and phloem boring } \\
\text { insects (borer species), } \\
\text { continental US }\end{array}$ & Loss in forest and urban trees & 2.5 \\
\hline [47] & Aquatic plants, UK & Control cost & 0.1 \\
\hline
\end{tabular}

The surveys reveal considerable damage costs of a specific species, in particular for aquatic weeds in US and fynbos in South Africa. [3] focused on damage costs of aquatic weeds in US and included relatively few studies, less than 10 studies, but with equal proportions on estimates of costs as reduction in recreational values or as control costs. [4] reviews more studies, approximately 30, and distinguish between ex-ante and ex-post studies, evaluate the methods used, and also discuss if and how uncertainty in the estimates were considered. They conclude that the majority of studies make ex-post valuations, use mainly control cost as a measure of damage costs or assess impacts on agriculture and sylvicultural sectors, and do not explicitly address uncertainty in effects or damages. [5] covered approximately 30 studies on aquatic HIS in addition to species specific studies, where most of the studies calculate costs of the zebra mussel (12), Sea lamprey (8), and aquatic weeds (8). The vast majority of studies estimate costs in terms of expenses for control of the species or as losses in profits or benefits for different production sectors, mainly fishery.

Except for [38], we present non-survey studies not included in any previous survey. The reason for including [38] is the early innovative approach with bio-economic modeling where the dynamics of the invader, comb jelly, was modelled together with resident species, anchovy, in order to calculate damage costs as losses in the fishery. A similar approach was applied by [39,40]. Econometric estimates of the dynamics of the invader, signal crayfish, and the endemic species, noble crayfish have been made [40]. Damage costs were then estimated as losses in the value of harvests of the noble crayfish. A bio-economic model of invasive aquatic plants (hydrilla, water hyacinth and water lettuce) is developed and applied to 13 large Florida lakes in the US [39]. Similarly, [44] estimates the potential economic impact of zebra mussel on consumptive water uses, recreational angling and wetland ecosystem services by using a probabilistic bio-economic simulation model under alternate policy scenarios. The model is then applied to Lake Okeechobee in Florida. Under the do nothing scenario (i.e., no public management), zebra mussels yield an adverse expected net economic impact of \$244.1 million. However, with public management (i.e., investment in prevention and eradication), we expect a net gain of $\$ 188.7$ million over a 20 -year planning horizon. Still in the state of Florida, [45] suggest that a state program being implemented beginning in the late 1990s to control invasive upland plants are very effective and could yield as much as \$865.1 million in present value net benefits through 2016 . 
Non-native forest insects have also been found to cause substantial costs to forests and urban trees. Suggestions are made that wood- and phloem-boring insects to both homeowners and municipal governments in excess of $\$ 2.5$ billion annually, with the largest economic cost imposed on local governments ( $\$ 1.7$ billion) [46].

Two of the studies, [41,42], apply choice experiment and hedonic methodologies, respectively, in assessing damage costs of aquatic invasive species. Costs of Yellow Floating Heart with respect to recreational values (bathing, boating and scenic beauty) were calculated for a small lake, Väringen, in mid Sweden, and found that recreational values of boating were most strongly affected by the weed [41]. The hedonic method was used by [42] by estimating the effects of aquatic invasive species, Eurosian Watermilfoil (milfoil), on property values across an extensive system of over 170 lakes in the northern forest region of Wisconsin. Based, on a spatial difference-in-differences specification, the results show that lakes invaded with milfoil experienced an average $13 \%$ decline in land values after invasion, and that the cost of an additional infested lake can be 0.0002 billion USD/year.

The use of control costs as a measure of damage costs has been used also in later studies, where [47] estimates that the Great Britain-wide cost of controlling is approximately 0.1 billion USD per annum. They also find cost estimates to be highest for Canadian pondweed (Elodea Canadensis) and zebra mussel (Dreissena polymorpha).

\section{Optimal Management of HIS}

While almost all studies presented in Section 3 calculate costs of species that have managed to pass all the stages in the invasions chain, several other studies instead focus on which stage to act against HIS. A general principle is that a certain amount of resources should be allocated where the give the greatest effect. This effect, in turn, depends on included time perspective, spatial connectivity, and uncertainty. A longer time perspective implies that actions today generate outcomes for a relatively long time, which is, however, counter acted by a positive discount rate which reduces the net value of future outcomes in present terms. The spatial dimension generates search for "hot spots", i.e., mitigation of HIS with relatively large potential of dispersal of damages. The consideration of uncertainty and existence of risk aversions in society favors actions that affect both expected and variability in damages. Most studies focus on one of these aspects, some of which are presented in the following.

\subsection{Optimal Prevention, Control and Adaptation Strategies}

A relatively large body of the literature on optimal management investigates the trade-offs between prevention, control, and adaptation strategies (e.g., [48-52]) or focus on the best practice within one of these stages by exploring dynamics of the invasive species and its interaction with resident species (e.g., [53-58]). The advantage of prevention measures is the avoidance of future damage costs in case of successful establishment and spread of the species under study. Disadvantages are that relatively more resources need to be spent on implementation of measures, such as inspection of vessels, at all possible entrance points, and that resources may be spent on prevention of harmless species. The relative advantage of control and adaptation measures is that they are directed towards definite invasions or damage (e.g., [50]). On the other hand, associated control costs can be large because of 
the difficulty of reducing the size and spread of the population since the risk of irreversible damage from potentially harmful species increases with time. The relative magnitude of these counteracting forces is, however, determined by the choice of discount rate, population sizes, and the rate of growth of the detected species. For example, the relatively high costs of complete eradication of an invader can be justified for relatively small population sizes with high growth rates [48]. Similar conclusions are obtained by [51] but in another setting where the role of cooperation between two countries, Canada and US is investigated. The results showed that it is economically efficient to allocate resources toward prevention in a cooperative strategy with a lower steady state stock of invasive species and damages to both countries, and that reactive and non-cooperative strategies imply that US and Canada are worse off than under any other scenario with the highest steady state stock of invasive species and damages.

Finnoff et al. [49] developed a bio-economic model to analyze the cost-effective management of invasions by accounting for feedbacks matter in the management of zebra mussels. Firms affected by zebra mussels, such as power plants and water treatment facilities, can apply control and adaptation measures as long as marginal benefits from control are higher than marginal costs. By introducing prevention and control, the policy maker can reduce the firm's incentives to implement control and adaptation measures. Escape of farmed salmon is treated as biological invasions by [52] and they show how the demand, recreational anglers, for salmon, wild and farmed, and cross breading affecting the growth rate and stock of salmon affects optimal control. When the anglers don not have specific preferences for wild salmon, a release may increase the overall net surplus of fishing, and a policy controlling the invasion would lead to a net loss for society.

Another class of studies investigates the implication of interactions between invader and resident species, and/or different age-classes of the invader and/or the resident species [53-58]. the An early study is provided by [53] on this topic, and he developed an economic model based on two principles - that the economic impacts imposed by the invader will depend on the exact nature of the interaction with the resident species in the host region. Explicit modeling of weed dynamics and interaction with grain production can improve precision in herbicide application and increase profits over time [54]. The optimal management of an invader, lake trout, in Yellow Stone lake which threatens the native cutthroat trout was analyzed by [55]. They pointed out the importance of hyperbolic discounting (where the discount rate is reduced over time) as compared to a constant rate. The hyperbolic discount rate favors relatively early prevention and control measures.

Buhle et al. [56] combined biological data on the population dynamics with control costs options to determine the minimum cost of a set of strategies for control of an established invader. They show by applying their model to oyster drills (Ocinebrellus inornatus) that the effective control strategies are sensitive to both life history and rate of population growth of the species. A contribution was made by [57] in the demonstrating the relative advantage of optimal control strategies based on removal rather than change of life histories for invasive species. With specific application to specific invasive species Spartina alterniflora in Willapa Bay, WA, they showed that the optimal strategy in any time period is prioritization of removal of a single age or stage class. Further, a numerical model is developed to analyze the role of species life history and age structure for optimal adaptation strategy by harvesting of a commercial resident species which compete for food and resource with the invader [59]. Using a bio-economic model of invader and resident species, they show the relevance of reproduction 
and mortality traits of both species and the age structure of the invader at the time of invasion. They also demonstrated that commercially harvested species with low juvenile survival and high reproduction are economically robust against invasions; and that species with such life-history are the most damaging.

\subsection{Spatial Dimension}

There is significant variation across spatially differentiated landscapes with respect to expected economic damages of invasive species to assets and expected costs of successful prevention and/or removal of the species. The key spatial concern is whether an ecosystem has a physical niche that can be exploited spatially by a new species, since establishment success and invasion magnitude are often created where resilience of an ecosystem is weak, for example due to environmental degradation (e.g., $([16,18,60])$. A review was carried out by [61] who observed that economic studies so far were either relatively simple either with respect to number of potential invasion sites, usually distinguishing between invaded and non-invaded regions, or with respect to assumption on heterogeneity among cites where many sites are included but assumed homogenous. They therefore developed a static model accounting for both heterogeneity and a large number of potential sites, and show that targeting of habitats affects cost effective control of the invader.

Subsequent studies explored the importance of heterogeneity and number of habitats (e.g., [60,62,63]). A spatial-dynamic model of optimal early detection and rapid response (EDRR) policies was developed by [60] and applied to Brown treesnake (Boiga irregularis) in Oahu, Hawaii. They found that myopic strategy where search only occurs when and where current expected net returns are positive is attractive to managers, and that early search of high priority areas can reduce control costs. The policy implication from their model is that extensive or non-targeted search is an ill-advised option. A spatially explicit two-dimensional model of species spread was developed by [62] that allows for differentiated control across space and time. They found that strategies targeted to slow or prevent spread of an invasion should be in the direction of greatest potential long-term damages. The importance of public attention was posited by [63] who showed that soliciting/enlisting the help of the public through "passive surveillance" enhances search effort in the face of resource constraint.

Using a spatially explicit simulation model of spread of a hypothetical invasive species, the roles of active and passive surveillance and their interaction are investigated. Sensitivity analysis revealed that it is generally optimal to allocate more funds during the first few years of a program, resulting in early eradication leading to smaller overall expenditures over the program cycle.

\subsection{Management under Uncertainty}

Several studies account for uncertainty when investigating the optimal choice of prevention, control, and adaptation [24,48,64-72]. In principle, these studies address similar questions as those presented in Section 3, i.e., the optimal combination of prevention, control and adaptation policies, but add the dimension of risk. This, in turn, makes it necessary to account for society's risk attitudes, which in general are guided by risk aversion. Available options are then to avoid outcomes with relatively large risks and/or to affect the risk by improving techniques for monitoring of HIS at the different stages in the invasion chain. 
Studies focusing on avoiding risk treat it as exogenous, and identify the best management strategy $[48,64,70,72]$. A relatively early contribution was provided by [64] where risk is assigned as a restriction in the decision problem. They present a quantitative bio-economic model to analyze risks from alien invasive species and apply it to the aquatic invasive species zebra mussels (Dreissena polymorphia) in US lakes. By applying stochastic dynamic programming, they identify the optimal allocation of resources to prevention as against control, acceptable invasion risks and effects of optimal allocation for investment purposes.

Other studies insert risk in the objective function [48,70,72]. It was shown by [48] that an increase in the likelihood of a larger introduction of invasive species leads to an increase in the absolute amount of prevention because of risk aversion. The previous modeling frameworks was extended by [70] by examining optimal allocation of prevention efforts as well as mitigation of impact of arrival of an invasion in an ecosystem hosting a renewable resource faced with threat of invasion. They showed that uncertainty in the timing and nature of an invasion are important for optimal management strategy for the native ecosystem. A more recent study was carried out by [72] who developed a bioeconomic model and used stochastic dynamic programming techniques to investigate when and to what extent to act in the invasion chain. Parameterizing the model framework for a potential Asian clam (Corbicula fluminea) invasion in the warm water discharge area of a nuclear plant on the northern shores of the Baltic sea, they found that choice of optimal strategy is highly sensitive to the unit costs and effectiveness of the required measures, level of externalities and the post detected invasion clam population size.

The studies that add the possibility of affecting risk focus mainly on improvements in monitoring efforts [68,69,73-77]. However, [68], who provided an early contribution to the treatment of risk as endogenous, showed how risk can be affected by prevention and control measures. The role of detection was addressed by [69] who argued that increasing resources to detection of invasive species increase managers' chances of finding a species at a smaller population level-lessening damages and control less costly and more effective. By capturing both stochastic and dynamic aspects, they illustrated that optimal detection strategy depends mainly on 'detectability' (ease of detection) and the biological relations of each distinct species.

A similar problem is modeled by [73] for controlling an invasive species in the presence of imperfect information about the extent of infestation. Modeling for optimal management as a function of beliefs about the level of infestation, they showed that the optimal policy involves choosing no action in the presence of a sufficiently large probability of no infestation and, with costless and perfect monitoring, expected costs change as the cost or quality of information from monitoring changes. The complementary role of passive surveillance by members of the public (i.e., enlist help of the public to detect infested sites) was explored by [75], and the results showed that increasing passive surveillance can reduce total cost and increase the probability of eradication.

Other studies investigate the effects of and possible adjustment to insufficient detection. A mathematical bio-economic model of zebra mussel invasion was developed by [77], which showed that slow response as a result of poor detection methods or inadequate control efforts would lead to a moderate probability of a significant infestation but that rapid reaction upon detection will reduce the probability of zebra mussels infecting a lake and generate much higher expected net benefits. A similar framework was used by [74] and the results indicate that spending time improving knowledge about a 
pest's habitat preferences before searching for it is optimal. Adaptation by chemical control was suggested by [76] as a substitute for poor detection equipment. They developed a bioeconomic model of integrated pest management strategies utilizing chemical and biological controls under uncertainty and irreversibility. Solving the general stochastic optimal control framework, they found that the introduction of natural predators is sufficient to manage infestation albeit chemical is considered effective when detection of infestation is delayed or when biological control agent fails to increase mortality of the invasive species.

\section{Choice of Policy Instruments}

The literature addressing the third main question posed by economic studies, optimal choice of policy instrument, analyses effects of policies at different stages in the invasion chain. However, the focus of most studies has been on prevention of species entrance into new regions by regulation of trade. The underlying premise for this focus on trade is perception of trade as an important vector of HIS. We therefore review studies that have attempted to estimate the explanatory power of trade in relation to other factors such as vulnerability of ecosystems or institutional aspects before presenting studies on prevention policies. In principle they can involve tariffs on trade and/or command and control policies, such as import bans or quarantine of contraband goods from entering certain geographical territories.

\subsection{International Trade as a Vector of HIS}

Increased globalization and the consequent effect on expanding world trade are recognized as the primary source of introduction of aquatic invasive species [1,24-26,78,79]. Aquarium fish trade is the source of at least 27 nonindigenous fish species established in continental U.S [1]. It is also estimated that 81 percent of invasive weeds entered the U.S. through commodity transport ([1,5]). It was also observed that increased rate of new invasions is also driven by human activities which creates diverse channels of transfer mechanisms (vectors) for movement of invasive organisms throughout the world [78]. In particular, ships are a leading source or dominant vector for biological invasions in coastal areas mainly through ballast water discharge (BWD) [79].

In analyzing the nexus between globalization, trade and the incidence of biological invasions, it is important to note that free trade serves an important springboard for increased specialization in production which also promotes specialization in ecosystems and biodiversity as well as improved standards of living [5,80-82]. For instance, [80] shows by combining a simple trade model with a species-area curve to derive the effect of trade on biodiversity conservation that when trading partners contain similar species in autarky, trade has little impact on global biodiversity but lowers local biodiversity. Conversely, specialization causes significant declines in both local and global biodiversity; but overall utility may decline with a move toward free trade in the absence of corrective conservation policy. Similarly, [82] study the linkage between protection from damages from invasive species within the context of two-way trade and trade integration. They conclude that invasive species damages induced by trade integration are most likely to increase because production does not fall as imports increase. 
It is well noted that quantifying a definitive link between trade and non-indigenous invasive species is very challenging and complicated [37,83] (see [84] for a synthesis of the trade and environment nexus). However, a number studies have attempted to estimate the explanatory power of trade for the occurrences of invasive species in different countries by the use of econometric tools [83,85-90].

Common to all studies is the inclusion of explanatory variables on openness of the economies to trade and on economics prosperity measured by GDP. It was found by [85] that both merchandize imports and import duties were of the expected signs (positive and negative respectively) albeit the former failing the test of statistical significance. In related and recent study, [87] modeled total number of biological invasions as dependent on openness to international trade and the health of the receiving ecosystem (induced by the level of anthropogenic disturbance due to local economic activities). Their results confirm theoretical prior by showing that trade, agricultural imports, factors of disturbance to local ecosystems are important drivers of biological invasion. A regression analysis was conducted by [86] of the density of alien plants in 28 European and North African countries using several land-use and socio-economic parameters as determinants, and established significant and positive impact of import trade as well as Human Development Index as key drivers of alien invasion plants. Historical data were used by [83] to parameterize species accumulation models by relating international trade to the establishment rates of nonindigenous species in the U.S. over the past century. The results show a relationship trade and exotic-species-accumulation curves similar to those developed for ecological sampling. Significant effects of trade were found by [88] on the occurrence of invasive species in countries, in particular on island nations. The importance of the combined effect of economic development and institutional capabilities was pointed out by [89], measured by corruption indexes, for the number of invasive species.

Another interesting discussion in the trade-HIS literature relates to how to design ideal policy interventions with respect to preventing high risk species import as against the impact of its establishment. Quantitative estimates were provided by [91] of the expected returns to a screening program relative to an open-door policy for imported reptiles and amphibians into the U.S. They estimate that the "...present value of expected net benefit per species assessed from implementing an optimal screening system ranges approximately from $\$ 54 \mathrm{~K}$ to $\$ 150 \mathrm{~K} "$. The results from their model lend support to the rationality of the risk assessment approach to evaluating policy options for preventing importation of HIS.

\subsection{Tariffs on Trade}

Thus, much evidence point to the important role of international trade as a vector of invasive species. Quite a few studies have looked at optimal design and application of import tariffs in general [82,92-97]. Several of these are reviewed in [6] where it is concluded that import tariffs on invasions risks may give rise to counter-productive increases in HIS. This may occur from economy wide adjustment where agriculture responds by increasing production and thereby susceptibility to invasions [94], through firms' speeding up of nursery sales of exotic plants before the tax introduction [92], or through lobbying groups' success in affecting the level and object of the tariff [93]. Studies comparing tariffs with a command and control type policy, namely port inspection, showed that it can be optimal for a host country to increase its inspection and decrease the tariff [95]. This 
counteracts higher domestic prices, and thereby reductions in consumer welfare and changes in land use, on rejected import goods. The focus in [97] was on how import tariffs can interact with other policies, such as agricultural policies for commodities. In their empirical illustration of the model to citrus canker, the authors revealed that an analysis that ignores the implications of import tariffs on other polices, such as crop insurance, might be misleading. Another aspect was presented by [96] who looked at existing tariff escalation in agro-forestry product markets and its implication for the risk invasive species. They found win-win situations where reduction of tariff escalation through lowering of tariff on processed goods increased allocative efficiency thereby reducing the invasive species externality.

\subsection{Non-Tariff Policies}

Despite the difficulties provided by WTO for introducing tariff policies for single countries, there are relatively few studies analyzing policies that are not related to international trade of goods and services [49,51,55,71,98-104]. A majority of these studies were reviewed by [6] and found that most of the studies analysed policies for control of an established species within a country. The policies investigated were compensation payments for control measures [105], trading market system and charges on ballast water for vessels [100,101]. One study investigated policies directed towards damage reduction by liability rules [98]. It was concluded that a main difficulty in designing policies is to relate a certain firm, or a vessel, with its spread or damage of HIS.

Later studies developed the uncertainty and/or spatial-dynamic consideration of policy design in order to improve the precision and effect on HIS and thereby the management cost (e.g., [71,103,104]). The optimal design of liability rules was analyzed by [102] when there is uncertainty in terms of asymmetric information, i.e., when the authority has less information than the regulated firm on, in this case, costs of controlling marine invasive species in maritime shipping - ballast water inside the ship and biofouling on the hulls outside the ship. The results showed that there is potential for a combination of incentive policies (liability with subsidies or liability with taxes) that can avert marine invasive species in cases of risk of damages and asymmetric information between ports and shippers. A contribution was made by [71] by addressing policy design for improving detection of HIS. They developed a spatially-explicit simulation model and demonstrated that mall increases in detection or reporting rates substantially reduce eradication costs and increase the probability of eradication. They surmised that the probability of passive detection is enhanced through awareness campaigns and bounty schemes that provide incentives to members of the public to search for and report detections (see [105] for details on the economics of monitoring versus incentives). Another perspective was used by [104] who considered uncertain and endogenous development of control and adaptation technologies, and found that it favors non-prevention policies.

\section{Conclusions}

The literature on the economics of invasive species management continues to engage the attention of researchers in recent years. This rapid development of the literature and its associated dynamics warrants an assessment of existing studies in the areas measurement of damages of invasive species, and costs-benefits of various management options. This paper reviews and updates the economics of invasive species management focusing on theories, models, impacts, measurements, uncertainty, 
spatial dynamics, international trade and the role of human behavior. The review shows that there is relatively many studies on estimation of damages costs of invasive species, which also appeared relatively early, in the 1980s. It is also evident that the estimated costs vary considerably among the studies, from less than 1 million USD per year to costs corresponding to $12 \%$ of gross domestic product for affected countries. This is explained by differences in methods, regional scale, and number of species included in the studies. Because of the sometimes very simplified methods there is a risk of overestimating the damage costs. On the other hand, the studies include only a fraction of the total number of invasive species which instead result in an underestimation of the costs of all HIS.

With respect to optimal choice of optimal management strategy, which involves decisions on when in the invasion chain to act and which policy instrument to use, there has been a rapid and interesting development during the last decade. In particular, with respect to the targeting of invasive species when they interact with other species, differ in survival and reproduction among age classes, and show uncertain spread in time and space in the landscape. During the last years, uncertainty has been tackled by search of information from improved monitoring techniques and efforts, which show that society could be better off from delayed mitigation action and instead invest in gaining more information on potential harms of the species under study. This contradicts to some extent the old finding of early detection and rapid response by eradication of (small) populations because of their potentially large damage and control costs of delayed action.

However, some urgent issues remain to be solved, which mainly involves design and evaluation of policies in practice. There has been much focus on theoretical optimal design of strategies, with relatively few empirical applications, although they are increasing. The policy studies have, to a large extent, investigated properties of different types of barriers to international trade, which is regarded as an important vector of HIS. Studies on which policies to use for mitigating established HIS by control or adaptation are more scant, but has increased in urgency because of the increasing number of established HIS in many countries. Another grey area of research in the literature on the economics of HIS is the evaluation of funding gaps for implementing control programs. Empirical evidence by [106,107] show from willingness-to-pay (WTP) studies for control of invasive species in the US that current federal governments' annual investments into control programs are much lower than observed in WTP studies - a case for additional management to reduce or eradicate HIS. This could be a potential area for future review studies as interest in the field grows.

Finally, many countries have introduced measures against HIS, such as measures to protect food safety, plant or animal health, which are allowed by the General Agreement on Tariffs and Trade (GATT) and the SPS, of the World Trade Organization (WTO). However, studies evaluating these measures and policies in practice are lacking, which we otherwise find for other environmental policies such as energy taxes or subsidies promoting renewable energy. In addition to learning from best policy practice, evaluation studies may raise other type of issues prevalent in practice, such as transaction costs and development of technologies for HIS mitigation, which remain to be addressed and analyzed.

\section{Acknowledgements}

We are much indebted to two anonymous referees for useful comments, and to the Swedish Research Fund, Formas, for financial support for the Extreame project. 


\section{Author Contributions}

George Marbuah, Ing-Marie Gren and Brendan McKie have all contributed substantially to the conceptualization and drafting of the paper. While George Marbuah and Ing-Marie Gren made inputs mainly from the economic perspective with respect to HIS, Brendan McKie provided invaluable contribution from the ecological perspective.

\section{Conflicts of Interest}

The authors declare no known conflict of interest.

\section{References}

1. OTA. Harmful Non-Indigenous Species in the United States; Office of Technology Assessment, U.S. Congress, OTA-F-565; U.S. Government Printing Office: Washington, DC, USA; Available online: http://www.wws.princeton.edu/ota/disk1/1993/9325_n.html (accessed on 1 August 2013).

2. Gren, I.-M.; Isacs, L.; Carlsson, M. Costs of alien invasive species in Sweden. Ambio 2009, 38, 135-140.

3. Rockwell, H.W., Jr. Summary of a survey of the literature on the economic impact of aquatic weeds. Available online: http://www.aquatics.org/pubs/economics (accessed on 3 September 2013).

4. Born, W.; Rauschmayer, F.; Bräuer, I. Economic Evaluation of Biological Invasions-A Survey. Ecol. Econ. 2005, 55, 321-336.

5. Lovell, S.J.; Stone, S. The Economic Impacts of Aquatic Invasive Species: A Review of the Literature; Working Paper \#05-02; National Center for Environmental Protection Agency, U.S. Environmental Protection Agency: Washington, DC, USA, 2005.

6. Gren, I.-M. Economics of alien invasive species management-Choices of targets and policies. Boreal Environ. Res. 2008, 13, 17-32.

7. Lodge, D.M.; Lewis, M.A.; Shogren, J.F.; Keller, R.P. Introduction to Biological Invasions: Biological, Economic and Social Perpectives. In Bioeconomics of Invasive Species; Keller, R., Lodge, D.M., Lewis, M.A., Shogren, J.F., Eds.; Oxford University Press: New York, NY, USA, 2009.

8. Williamson, M.; Fitter, A. The varying success of invaders. Ecology 1996, 77, 1661-1666.

9. Williamson, M.; Fitter, A. The characteristics of successful of invaders. Biol. Conservat. 1996, 78, 163-170.

10. Jeschke, J.M.; Strayer, D.L. Invasion success of invertebrates in Europe and North America. Proc. Natl. Acad. Sci USA 2005, 102, 7198-7202.

11. Jeschke, J.M. Across islands and continents, mammals are more successful invaders than birds. Divers. Distrib. 2008, 14, 913-916.

12. Crowl, T.A.; Crist, T.O.; Parmenter, R.R.; Belovsky, G.; Lugo, A.E.A. The spread of invasive species and infectious disease as drivers of ecosystem change. Front. Ecol. Environ. 2008, 6, 238-246.

13. Strayer, D.L. Alien species in fresh waters: Ecological effects, interactions with other stressors, and prospects for the future. Freshwat. Biol. 2010, 55, 152-174. 
14. Mack, R.N.; Simberloff, D.; Lonsdale, W.M.; Evans, H.; Clout, M.; Bazzaz, F.A. Biotic invasions: Causes, epidemiology, global consequences, and control. Ecol. Appl. 2000, 10, 689-710.

15. Crooks, J.A. Characterizing ecosystem-level consequences of biological invasions: The role of ecosystem engineers. Oikos 2002, 97, 153-166.

16. Hellmann, J.J.; Byers, J.E.; Bierwagen, B.G.; Dukes, J.S. Five potential consequences of climate change for invasive species. Conservat. Biol. 2008, 22, 534-543.

17. Gonzalez, A.L.; Kominoski, J.S.; Danger, M.; Ishida, S.; Iwai, N.; Rubach, A. Can ecological stoichiometry help explain patterns of biological invasions? Oikos 2010, 119, 779-790.

18. Schweiger, O.; Biesmeijer, J.C.; Bommarco, R.; Hickler, T.; Hulme, P.E.; Klotz, S.; Kühn, I.; Moora, M.; Nielsen, A.; Ohlemüller, R.; et al. Multiple stressors on biotic interactions: How climate change and alien species interact to affect pollination. Biol. Rev. 2010, 85, 777-795.

19. Prenter, J.; MacNeil, C.; Dick, J.T.A.; Dunn, A.M. Roles of parasites in animal invasions. Trends Ecol. Evol. 2004, 19, 385-390.

20. Ellison, A.M.; Bank, M.S; Clinton, B.D; Colburn, E.A; Elliott, K.; Ford, C.R.; Foster, D.R.; Kloeppel, B.D.; Knoepp, J.D.; Lovett, G.M.; et al. Loss of foundation species: Consequences for the structure and dynamicsof forested ecosystems. Front. Ecol. Environ.2005, 3, 479-486.

21. Lovett, G.M.; Canham, C.D.; Arthur, M.A.; Weathers, K.C.; Fitzhugh, R.D. Forest ecosystem responses to exotic pests and pathogens in eastern North America. Bioscience 2006, 56, 395-405.

22. Charles, H.; Dukes, J.S. Impacts of invasive species on ecosystem services. Ecol. Stud. 2007, 193, 217-237.

23. Lodge, D.M.; Williams, S.; MacIsaac, H.; Hayes, K.; Leung, B.; Reichard, S.; Mack, R.N.; Moyle, P.B.; Smith, M.; Andow, D.A.; et al. Biological invasions: recommendations for U.S. policy and management. Ecol. Appl. 2006, 16, 2035-2054.

24. Perrings, C. Mitigation and adaptation strategies for the control of biological invasions. Ecol. Econ. 2005, 52, 315-325.

25. Perrings, C.; Williamson, M.; Barbier, E.B.; Delfino, D.; Dalmazzone, S.; Shogren, J.; Simmons, P.; Watkinson, A. Biological invasion risks and the public good: An economic perspective. Conservat. Ecol. 2002, 6, 1.

26. Perrings, C.; Fenichel, E.; Kinzig, A. Globalization and invasive alien species: Trade, pests, and pathogens. In Bioinvasions and Globalization: Ecology, Economics, Management, and Policy; Perrings, C., Mooney, H., Williamson, M., Eds.; Oxford University Press: New York, NY, USA, 2010.

27. Epanchin-Niell, R.S.; Hastings, A. Controlling established invaders: Integrating economics and spread dynamics to determine optimal management. Ecol. Lett. 2010, 13, 528-541.

28. Turner, R.K.; Paavola, J.; Cooper, P.; Farber, S.; Jessamy, V.; Georgiou, S. Valuing nature: Lessons learned and future research directions. Ecol. Econ. 2003, 46, 493-510.

29. Pimentel, D.; McNair, S.; Janecka, J.; Wightman, J.; Simmonds, C.; O’Connell, C.; Wong, E.; Russel, L.; Zern, J.; Aquino, T.; et al. Economic and environmental threats of alien plant, animal, and microbe invasions. Agr. Ecosyst. Environ. 2001, 84, 1-20.

30. Pimentel, D.; Zuniga, R.; Morrison, D. Update on the environmental and economic costs associated with alien-invasive species in the United States. Ecol. Econ. 2005, 52, 273-288. 
31. Kelly, J.; Tosh, D.; Dale, K.; Jackson, A. The Economic cost of invasive and non-native species in Ireland and Northern Ireland; Invasive species Ireland: Belfast, Northern Ireland, 2013. Available online: http://invasivespeciesireland.com/background/economic-impacts/ (accessed on 3 September 2013).

32. Reinhardt, F.; Herle, M.; Bastiansenn, F.; Streit, B. Economic Impact of The Spread of Alien Species in Germany; Report No. UBA-FB; Federal Environmental Agency: Berlin, Germany, 2003.

33. Colautti, R.I.; Bailey, S.A.; van Overdijk, C.D.A.; Amundsen, K.; MacIsaac, H.J. Characterized and projected costs of nonindigenous species in Canada. Biol. Inv. 2006, 8, 45-59.

34. Pimentel, D.; Lach, L.; Zuniga, R.; Morrison, D. Environmental and economic costs of nonindigenous species in the United States. BioScience 2000, 50, 53-65.

35. Pimentel, D. Environmental and economic costs of vertebrate species invasions into the United States. Managing Vertebrate Invasive Species; University of Nebraska: Lincoln, NE, USA, 2007. Available online: http://digitalcommons.unl.edu/cgi/ viewcontent.cgi?article $=1037 \&$ context $=$ nwrcinvasive (accessed on 12 August 2013).

36. McDermott, S.M.; Finnoff, D.C.; Shogren, J.F. The welfare impacts of an invasive species: Endogenous vs. exogenous price models. Ecol. Econ. 2013, 85, 43-49.

37. Lovell, S.J.; Stone, S.F.; Fernandez, L. The economic impacts of aquatic invasive species: A review of the literature. Agr. Resour. Econ. Rev. 2006, 35, 195-208.

38. Knowler, D.; Barbier, E. The economics of an invading species: A theoretical model and case study application. In The Economics of Biological Invasions; Perrings, C., Williamson, M. Dalmazzone, S., Eds.; Edward Elgar: Cheltenham, UK, 2000; pp.70-93.

39. Adams, D.C.; Lee, D.J. Estimating the value of invasive aquatic plant control: A bioeconomic analysis of 13 public lakes in Florida. J. Agr. Appl. Econ. 2007, 39, 97-109.

40. Kataria, M. A cost-benefit analysis of introducing a non-native species: The case of signal crayfish in Sweden. Mar. Resour. Econ. 2007, 22, 15-28.

41. Carlsson, F.; Kataria, M. Assessing management options for weed control with demanders and non-demander in a choice experiment. Land Econ. 2008, 84, 517-528.

42. Horsch, E.J.; Lewis, D.J. The effects of aquatic invasive species on property values: Evidence from a quasi-random experiment. Land Econ. 2009, 85, 391-409.

43. Pejchar, L.; Mooney, H. The impact of invasive alien species on ecosystem services and human well-being. In Bioinvasions \& Globalization: Ecology, Economics, Management, and Policy; Perrings, C., Mooney, H., Williamson, M., Eds.; Oxford University Press: New York, NY, USA, 2010.

44. Lee, D.J.; Adams, D.C.; Rossi, F. Optimal management of a potential Invader: The case of zebra mussels in Florida. J. Agr. Appl. Econ. 2007, 39, 69-81.

45. Lee, D.J.; Adams, D.C.; Kim, C.S. Managing invasive plants on public conservation forestlands: Application of a bio-economic model. Forest Pol. Econ. 2009, 11, 237-243.

46. Aukema, J.E.; Leung, B.; Kovacs, K.; Chivers, C.; Britton, K.O.; Englin, J.; Rrankel, S.J.; Haight, R.G.; Holmes, T.P.; Liebhold, A.M.; et al. Economic impacts of non-native forest insects in the continental United States. PLoS One 2011, 6, 1-7. 
47. Oreska, M.P.J.; Aldridge, D.C. Estimating the financial costs of freshwater invasive species in Great Britain: A standardized approach to invasive species costing. Biol. Invasions 2011, 13, 305-319.

48. Olson, L.J.; Roy, S. On prevention and control of an uncertain biological invasion. Rev. Agr. Econ. 2005, 27, 491-497.

49. Finnoff, D.; Shogren, J.F.; Leung, B.; Lodge, D. The importance of bioeconomic feedback in invasive species management. Ecol. Econ. 2005, 52, 367-381.

50. Finnoff, D.; Shogren, J.; Leung, B.; Lodge, D. Take a risk: Preferring prevention over control of biological invaders. Ecol. Econ. 2007, 62, 216-222.

51. Fernandez, L. Maritime trade and migratory species management to protect biodiversity. Environ. Res. Econ. 2007, 38, 165-188.

52. Olaussen, J.O.; Skonhoft, A. On the economics of biological invasion: An application to recreational fishing. Nat. Resour. Model. 2008, 21, 625-653.

53. Barbier, E.B. A note on the economics of biological invasions. Ecol. Econ. 2001, 39, 197-202.

54. Wu, J. Optimal weed control under static and dynamic decision rules. Agr. Econ. 2001, 25, 119-130.

55. Settle, C.; Shogren, J.F. Modeling native-exotic species within Yellowstone lake. Am. J. Agr. Econ. 2002, 84, 1323-1328.

56. Buhle, E.R.; Margolis, M.; Ruesink, J.L. Bang for buck: Cost-effective control of invasive species with different life histories. Ecol. Econ. 2005, 52, 355-366.

57. Hastings, A.; Hall, R.J.; Taylor, C.M. A simple approach to optimal control of invasive species. Theor. Popul. Biol. 2006, 70, 431-435.

58. Elofsson, K.; Bengtsson, G.; Gren, I.-M. Optimal management of invasive species with different reproduction and survival strategies. Nat. Resour. Model. 2012, 25, 599-628.

59. Elofsson, K.; Gren, I.-M. Control and adaptation strategies for invasive species with different life history. In Proceedings of the EAERE 19th Annual Conference, Prague, Czech Republic, 27-30 June 2012.

60. Kaiser, B.A.; Burnett, K.M. Spatial economic analysis of early detection and rapid response strategies for an invasive species. Resour. Energ. Econ. 2010, 32, 566-585.

61. Touza, J.; Drechsler, M.; Johst, K.; Dehnen-Schmutz, K. The role of space in invasive species management. In Bioinvasions \& Globalization: Ecology, Economics, Management, and Policy; Perrings, C., Mooney, H., Williamson, M., Eds.; Oxford University Press: New York, NY, USA, 2010.

62. Epanchin-Neill, R.S.; Wilen, J.E. Optimal Control of Spatial-Dynamic Processes: The Case of Biological Invasions; Discussion Paper \# DP 11-07; Resources for the Future: Washington, DC, USA, 2011.

63. Hester, S.; Cacho, O. Optimization of search strategies in managing biological invasions: A simulation approach. Hum. Ecol. Risk Assess. An Int. J. 2012, 18, 181-199.

64. Leung, B.; Lodge, D.M.; Finnoff, D.; Shogren, J.F.; Lewis, M.A.; Lamberti, G. An ounce of prevention or a pound of cure: bioeconomic risk analysis of invasive species. P. Roy. Soc. Lond. B 2002, 269, 2407-2413.

65. Olson, L.J.; Roy, S. The economics of controlling a stochastic biological invasion. Am. J. Agric. Econ. 2002, 84, 1311-1316. 
66. Olson, L.J.; Roy, S. The Economics of Controlling a Biological Invasion; Working Paper \#03-06; Department of Agricultural and Resource Economics, University of Maryland: College Park, MD, USA, 2003.

67. Eiswerth, M.E.; Johnson, W.S. Managing nonindigenous invasive species: Insights from dynamic analysis. Environ. Resour. Econ. 2002, 23, 319-342.

68. Finnoff, D.; Shogren, J.F. Endogenous risk as a tool for nonindigenous species management. Weed Contr. 2004, 18, 1261-1265.

69. Mehta, S.V.; Haight, R.G.; Homans, F.R.; Polasky, S.; Venette, R.C. Optimal detection and control strategies for invasive species management. Ecol. Econ. 2011, 61, 237-245.

70. Ranjan, R.; Marshall, E.; Shortle, J. Optimal renewable resource management in the presence of endogenous risk of invasion. J. Environ. Manag. 2008, 89, 273-283.

71. Cacho, O.J.; Spring, D.; Hester, S.; Nally, R.M. Allocating surveillance effort in the management of invasive species: A spatially-explicit model. Environ. Model. Software. 2010, 25, 444-454.

72. Hyytiäinen, K.; Lehtniemi, M.; Niemi, J.K.; Tikka, K. An optimization framework for addressing aquatic invasive species. Ecol. Econ. 2013, 91, 69-79.

73. Haight, R.G.; Polasky, S. Optimal control of an invasive species with imperfect information about the level of infestation. Resour. Energ. Econ. 2010, 32, 519-533.

74. Baxter, P.W.J.; Possingham, H.P. Optimizing search strategies for invasive pests: Learn before you leap. J. Appl. Ecol. 2011, 48, 86-95.

75. Cacho, O.J.; Hester, S.M. Deriving efficient frontiers for the effort allocation in the management of invasive species. Aust. J. Agr. Resour. Econ. 2011, 55, 72-89.

76. Marten, A.L.; Moore, C.C. An options based bioeconomic model for biological and chemical control of invasive species. Ecol. Econ.2011, 70, 2050-2061.

77. Adams, D.C.; Lee, D.J. Technology adoption and mitigation of invasive species damage and risk: Application to zebra mussels. J. Bioecon. 2012, 14, 21-40.

78. Ruiz, G.M.; Murphy, K.R.; Verling, E.; Smith, G.; Chaves, S.; Hines, A.H. Ballast water exchange: Efficiency of treating ships' ballast water to reduce marine species transfers and invasion success? Smithsonian Environmental Research Center: Edgewater, MD, USA, 2005.

79. McGee, S.; Piorkowski, R.; Ruiz, G. Analysis of recent vessel arrivals and ballast water discharge in Alaska: Toward assessing ship-mediated invasion risk. Mar. Pollut. Bull.2006, 52, 1634-1645.

80. Polasky, S.; Costello, C.; McAusland, C. On trade, land-use, and biodiversity. J. Environ. Econ. Manag. 2004, 48, 911-925.

81. Jenkins, P.T. Free trade and exotic species introductions. Conservat. Biol. 1996, 10, 300-302.

82. Tu, A.; Beghin, J. Intra-Industry Trade, Multilateral Trade Integration, and Invasive Species Risk; Working Paper \# 06-WP 439; Center for Agricultural and Rural Development, Iowa State University: Ames, IA, USA, 2006.

83. Levine, J.M.; D’Antonio, C.M. Forecasting biological invasions with increasing international trade. Conservat. Biol. 2003, 17, 322-326.

84. Copeland, B.R.; Taylor, M.S. Trade and the environment: A partial synthesis. Am. J. Agr. Econ. 1995, 77, 765-771. 
85. Dalmazzone, S. Economic factors affecting the vulnerability of biological invasions. In The Economics of Biological Invasions; Perrings, C., Williamson, M., Dalmazzone, S. Eds.; Edward Elgar Publishing: Cheltenham, UK, 2000. pp. 17-30.

86. Vilà, M.; Pujadas, J. Land-use and socio-economic correlates of plant invasions in European and North African countries. Biol. Conservat. 2001, 100, 397-401.

87. Giaccaria, S.; Dalmazzone, S. Socio-Economic Drivers of Biological Invasions. A World-Wide, Bio-Geographical Analysis of Trade Flows and Local Environmental Quality; Working Paper \# 03/2010; Department of Economics, Università di Torino: Torino, Italy, 2010.

88. Gren, I.-M.; Thierfelder, T.; Berglund, H. Country characteristics and non-indigenous Species. Environ. Dev. Econ. 2010, 18, 51-70.

89. Gren, I.-M.; Campos, M. Development and non-indigenous species. Reg. Environ. Change. 2011, 11, 593-601.

90. Springborn, M.; Romagosa, C.M.; Keller, R.P. The value of nonindigenous species risk assessment in international trade. Ecol. Econ. 2011, 70, 2145-2153.

91. Dalmazzone, S.; Giaccaria, S. Economic drivers of biological invasions. A World-Wide, Bio-Geographical Analysis; Working Paper \# 15/2010; Department of Economics, Università di Torino: Torino, Italy, 2012.

92. Knowler, D.; Barbier, E.B. Importing exotic plants and the risk of invasion: Are market-based instruments adequate? Ecol. Econ. 2005, 52, 341-354.

93. Margolis, M.; Shogren, J.F.; Fischer, C. How trade politics affect invasive species control. Ecol. Econ. 2005, 52, 305-313.

94. Costello, C.; McAusland, C. Protectionism, trade and measures of damage from exotic species introductions. Am. J. Agr. Econ. 2003, 85, 964-975.

95. McAusland, C.; Costello, C. Avoiding invasives: Trade-Related policies for controlling unintentional exotic species introductions. J. Environ. Econ. Manag. 2004, 48, 954-977.

96. Tu, A.; Beghin, J.; Gozlan, E. Tariff escalation and invasive species risk; Working Paper \# 05WP 407, Center for Agricultural and Rural Development, Iowa State University: Ames, IA, USA, 2005.

97. Acquaye, A.K.A.; Alston, J.M.; Lee, H.; Sumner, D.A. Economic consequences of invasive species policies of commodity programs: Theory and applications to citrus canker. Rev. Agr. Econ. 2005, 27, 498-504.

98. Thomas, M.; Randall, A. Intentional introduction of nonindigenous species: a principal-agent model and protocol for revocable decisions. Ecol. Econ. 2000, 34, 333-345.

99. Jetter, K.; DiTomaso, J.; Drake, L.; Klonsky, K.; Pitcairn, M.; Summer, D. Biological control of yellow starthistle. In Exotic pests and diseases: biology and economics for biosecurity; Summer, D., Ed.; Iowa State University Press: Ames, IA, USA, 2003; pp. 225-241.

100. Horan, R.D.; Lupi, F. Economic incentives for controlling trade-related biological invasions in the Great Lakes. Agr. Resour. Econ. Rev. 2005, 34, 75-89.

101. Jones, K.R.; Corona, J.P. An ambient tax approach to invasive species. Ecol. Econ. 2008, 64, 534-541.

102. Fernandez, L. NAFTA and member country strategies for maritime trade and marine invasive species. J. Environ. Manag. 2008, 89, 308-321. 
103. Cordell, J.R.; Lawrence, D.J.; Ferm, N.C.; Tear, L.M.; Smith, S.S.; Herwig, R.P. Factors influencing densities of non-indigenous species in the ballast water of ships arriving at Ports in Puget Sound, Washington, United States. Aquat. Conservat. Mar. Freshwat. Ecosyst. 2009, 19, 322-343.

104. Kim, C.S.; Ailllery, M.; Lewandrowski, J.; Kim, S.G. Optimal policies for managing invasive species under uncertainty. Appl. Math. 2012, 3, 1388-1394.

105. Demougin, D.; Fluet, C. Monitoring versus incentives. European Economic Review 2001, 45, 1741-1764.

106. McIntosh, C.R.; Shogren, J.G.; Finnoff, D.C. Invasive species and delaying the inevitable: Valuation evidence from a national survey. Ecol. Econ. 2010, 69, 632-640.

107. Adams, D.C.; Bwenge, F.; Lee, D.J.; Larkin, S.; Alavalapati, J.R.R. Public preferences for controlling upland invasive plants in state parks, Application of a choice model. Forest. Pol. Econ. 2011, 13, 465-472.

(C) 2014 by the authors; licensee MDPI, Basel, Switzerland. This article is an open access article distributed under the terms and conditions of the Creative Commons Attribution license (http://creativecommons.org/licenses/by/3.0/). 